\title{
From techno talk to social reflection
}

In politics many things depend on how an issue is framed from different points of view, including science and technology, society and public engagement. This threefold-framing of converging technologies has shaped the political and public debate on the topic. What are the lessons for the role of public participation in the field of converging technologies?

By Rinie van Est

A round the turn of the century, the convergence of Nanotechnology, Biotechnology, Information technology and Cognitive science (NBIC) was framed as the new technology wave; a next phase within the ongoing information revolution (van Est et al. 2006). Technological convergence created a new set of engineering ambitions with regards to biological and cognitive processes.

\section{Techno talk}

Within bio-cogno-engineering two trends can be discerned: First, the set of engineering tools to intervene in living organisms and second, the engineering capacity to create technology with the specific life-like characteristics of living organisms. Arthur refers to these two trends as "biology is becoming technology" and "technology is becoming biology", respectively (Arthur 2009).

The upcoming intellectual debate around NBIC convergence can be characterized by two perspectives. On the one hand convergence is seen as a key factor driving the development and organization of the natural sciences. The other side of convergence is explicitly value-loaded. According to Staman: “The concept implies that nanosciences and convergence (should) break through the boundaries of man, nature and technological artifacts" (Staman 2004).

With regards to "biology is becoming technology" we have seen many debates on the use of recombinant-DNA technology to create new kinds of micro-organisms, plant and animal life forms by modifying existing ones. Following up on these debates, NBIC convergence has led to a growing international debate on human enhancement, that is, the promises and perils of engineering the human body and mind (van Est et al. 2006; Van Est et al. 2008a).

The debate on "technology is becoming biology" is about fear of loss of control. Joy stated that the living character of gene tech- nology, nanotechnology and robotics are "threatening to make humans an endangered species," because they bring the processes of self-reproduction and evolution within the realm of human intervention. The Grey Goo scenario dominated the early stages of the nanodebate, but was removed from the agenda. Developments in synthetic biology and robotics are currently breathing new life in this discussion theme.

It is expected that converging technologies will lead to a wide range of heated social and ethical debates. This future vision ensures that the question about the role and purpose of science and technology in our culture is once again being emphatically posed.

\section{Engagement talk}

How has the governance of the interaction between science, technology and society been framed over the last few decades? To answer this question special attention has to be paid to the relationship between converging technologies and public participation.

Many authors have criticized from a democratic perspective the separation between the promotion and regulation of technology. The main argument is that this dual track approach positions the development of science and technology as a neutral, value-free process, while politics is left with the task of mitigating its negative side effects in society. The history of technology assessment (TA) shows various attempts to address the gap between innovation and regulation. Parliamentary TA informs about potential social impacts of emerging technologies. Participatory TA deals with the interface between the political decision-making arena and society (Joss/Bellucci 2002). This type of TA is inspired by a deliberative model of democracy. Constructive TA (CTA) employs the same toolbox. CTA is not directed toward influencing regulatory practices, but wants to address social issues around technology by influencing design practices (Rip et al. 1995). From a democratic view, CTA thus aims to open up or politicize the development of science and technology.

\section{The promise of upstream engagement}

At the beginning of this century, concerns about the sciencesociety relationship and calls for public dialogue became part of the mainstream policy discourse in Europe and, to a lesser extent, in America. The arrival of nanotechnology and NBIC created an opportunity to renew the debate on the interaction between science and society. Elaborating on developments in $\rightarrow$ 
the field of participatory and constructive TA, concepts like upstream regulation of science and technology and upstream public participation entered the discourse. On the European level this has led to the formulation of the goal of responsible development of nanosciences and nanotechnologies, and a code of conduct for assuring that (Schomberg 2010).

To what extent has the threefold-framing of techno-, socio-, and public engagement talk impacted the political and public debate on converging technologies, including nanotechnology and synthetic biology, so far. To answer this question I look at the involvement of policy makers and non-governmental organizations (NGOs), at polls on public awareness, and the impact of organized public deliberation processes.

\section{Slowly entering the minds of policy makers}

The most striking fact about public engagement on converging technologies is the lack of knowledge amongst the public in general, but also amongst political actors and other stakeholders (Hanssen et al. 2008; Stø et al. 2010). In the 1990s policy makers' focus was on biotechnology. During the first decade of this century nanotechnology has captured their attention. With respect to nanotechnology a lot of effort has been put on the issue of nanosafety. The concept of converging technologies as such, however, is only gradually entering the minds of policy makers. Thus from a policy perspective the use of the converging technologies as a way of framing issues and setting agendas is still in an embryonic stage. In this phase mainly the research and TA community frame the issue and try to inform politicians and policy makers about the social significance of converging technologies (Van Est et al. 2006; 2010). Also some NGOs have paid attention to converging technologies. Almost all public deliberation processes, however, are set up from the perspective of nanotechnology. The notion of converging technologies may play a role in that type of debates. In fact this may foster discussing the broader social and ethical issues that are raised by nanotechnology (Hanssen et al. 2008).

Three pre-eminent organizations, ETC group, Friends of the Earth and Greenpeace, are setting the more critical tone for the debate on nanotechnology and converging technologies during the early stage. Already in 2003 Greenpeace UK published the study Future technologies, Today's choices and organized debates around it (Arnall 2003). In the same year the Canadian ETC Group published their report 'The big down', about possible ethical and ecological consequences of nanotechnology, as a driving force of converging technologies. Partly based on this preparatory work other societal organizations, like labor unions, environmental organizations and Christian churches, have set up conferences and published reports.

With regards to the involvement of the wider public, surveys reveal a significant lack of public awareness with regards to nanotechnology or synthetic biology (Hanssen et al. 2008). About 70 percent of the American respondents and 60 percent of their European counterparts have never heard of nanotechnology.
And these percentages have changed little of the last few years. In contrast, the proportion of American adults that have heard about synthetic biology has increased from nine to 22 percent during 2008.

\section{Organized public participation}

With respect to public participation on nanotechnology, between 2004 and 2008 more than 60 initiatives have been taken in various European countries, America and Australia to involve citizens and consumers in deliberative processes (Stø et al. 2010). Over the years, the focus of these processes has shifted from general discussions to debates on more specific application-domains.

Over the last years countries, like France and the Netherlands, have initiated larger scale debates. From October 2009 to February 2010, the French Commission of Public Debates has set up a series of public debates on nanotechnology. These activities have been accused of being "government-controlled, through money or affiliation, rather than independent voices" (McAlpine 2010). Some debates even have to be held without public because of protestors raising slogans such as "Nano, it's not green. It's totalitarian” (McAlpine 2010). The Dutch national societal debate on genetically modified food in 2001 had triggered somewhat similar criticism. Environmental NGOs had distanced themselves from the debate in an early stage because they thought that the no- genetically modified-food option was not part of the debate. Having learned from this failure, the Netherlands has taken a rather different approach. In the case of nanotechnology an independent committee invites individuals and organizations to propose activities to stimulate dialogue. The Dutch dialogue can be seen as a government-initiated bottom-up process. This debate runs from December 2009 to 2010 and has to result into a public agenda for nanotechnology, which will be used as a non-binding input for Dutch policies on nanotechnology.

Stø et al. hold that it is currently difficult to assess the actual impact of these deliberations due to a lack of data, specified goals and information about dissemination activities (Stø et al. 2010). In particular deliberative processes driven by academia have a minor impact on decision-making, because they lack a clear link to policy makers. Nevertheless, some of these academic exercises have provided a profound understanding of ways in which laypeople grapple with the meaning of emerging nanotechnologies.

\section{To summarize}

Converging technologies represent a new technology wave and shows two bioengineering trends: "biology is becoming technology" and "technology is becoming biology". For the first time in history the organic world appears to become mouldable in the sense that it can be controlled, designed and built. This new technology wave will have a profound influence on 
society and will even influence what it means to be human. Besides all kinds of desirable applications, "biology is becoming technology" raises fear for total technological control over life. The trend "technology is becoming biology" goes hand in hand with a fear of loss of human control over our technology. To deal with this new technology wave both policy making regulation and public participation have to move upstream to guide technological development and visions from a social and public point of view.

Up to now, basically experts from the natural and social scientists and humanities are involved in discussions on converging technologies. Policy makers are gradually picking up the term, and some trendsetting NGOs have commented from a societal perspective on converging technologies. Policy makers and the public debate mainly focus on nanotechnology, and to a lesser extent on synthetic biology. The public talk echoes moral and ethical notions which have also been put forward by social scientists and NGOs, and show that such philosophical considerations have a clear footing in the public mind.

\section{Public participation as upstream social reflection}

During the arrival of nanotechnology it was held that public participation needed to move upstream in order to guide research and development and the regulation of emerging technologies from a societal perspective. Such a direct political impact on decision making has not materialized to any extent. This doesn't mean that public participation is just a dog without teeth. Public participation plays a major role in shaping socio-talk and public talk. This is highly needed to complement the massive and influential techno-talk presented by nanotechnology, synthetic biology and the mega story-line of converging technologies. Building up such a social and cultural information basis is a prerequisite for a mature political and public debate.

Maybe the promise of upstream involvement of the public and dialogue has created a certain disdain for informing people, experts, politicians and normal citizens alike. This would be a big mistake. But instead of returning to public understanding of science, efforts should be undertaken to heighten public understanding of science in society. What I see happening is upstream reflection from a social and ethical perspective on various converging technologies. The engagement of a wide diversity of publics is needed for that: technologists, social scientist, experts, politicians, policy makers, large and small NGOs, artists, engaged publics as well as disinterested laypeople.

\section{References}

Arnall, A.H.: Future technologies, Today's choices. Nanotechnology, artificial intelligence and robotics; a technical, political and institutional map of emerging technologies. London 2003.

Arthur, W.B.: The nature of technology: What it is and how it evolves. London 2009.

ETC Group: The Big Down: From genomes to atoms. Atomtech: Technologies converging at the nano-scale. Winnipeg 2003.
Hanssen, L. / Walhout, B. / van Est, R.: Ten lessons for a nanodialogue: The debate on nanotechnology thus far. The Hague 2008.

Joss, S. / Bellucci, S. (eds.): Participatory Technology Assessment: European perspectives. London 2002

McAlpine, K.: Chaos at French nanotech debates. In: Chemistry World (January 22, 2010). Internet: http://www.rsc.org/chemistryworld/News/2010/ January/22011001.asp (last accessed on April 2, 2010).

Rip, A. / Misa, T.J. / Schot, J.: Constructive technology assessment: A new paradigm for managing technology in society. In: Rip, A. / Misa, T.J. / Schot, J. (eds.): Managing technology in society: The approach of constructive technology assessment. London, New York 1995.

Roco, M. / Bainbridge, W.S. (eds.): Converging technologies for improving human performance: Nanotechnology, biotechnology, information technology and cognitive sciences. Arlington 2002.

Schomberg, R. von: Introduction: Understanding public debate on nanotechnologies options for framing debate. In: Schomberg, R. von / Davies, S. (eds.): Understanding public debate on nanotechnologies: Options for framing public policy. Brussels 2010.

Staman, J.: Ethical, legal, and societal aspects of the converging technologies (NBIC). Special Interest Group II. Draft report to HLEG Foresighting the Next Technology Wave. Brussels 2004.

Stø, E. / Scholl, G. / Jègou, F. / Strandbakken, P.: The future of deliberative processes on nanotechnology. I n: Schomberg, R. von / Davies, S. (eds.): Understanding public debate on nanotechnologies: Options for framing public policy. Brussels 2010.

Van Est, R. / Enzing, C. / van Lieshout, M. / Versleijen, A.: Welcome to the 21 st century: Heaven, hell or down to earth? A historical, public debate and technological perspective on the convergence of nanotechnology, biotechnology, information technology and the cognitive sciences. Brussels 2006.

Van Est, R. / Klaassen, P. / Schuijff, M. / Smits, en M.: Future man - No future man: Connecting the cultural, political and technological dots of human enhancement. The Hague 2008a.

Van Est, R. / Walhout, B. / Hanssen, L.: Ten lessons for a nanodialogue: How to be deadly serious and still have serious fun. The Hague $2008 \mathrm{~b}$.

Van Est, R. / van Keulen, I. / Geesink, I. / Schuijff, M.: Making perfect life: Bio-engineering (in) the 21 st century. Brussels 2010.

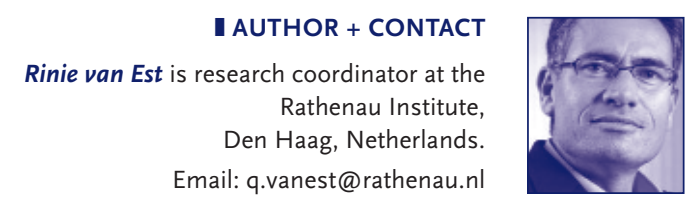


(c) 20I0 Authors; licensee IÖW and oekom verlag. This is an article distributed under the terms of the Creative Commons Attribution Non-Commercial No Derivates License (http://creativecommons.org/licenses/by-nc-nd/3.o/), which permits unrestricted use, distribution, and reproduction in any medium, provided the original work is properly cited. 